\title{
Analisis Hara Cu dan Zn pada Vegetasi Gulma sebagai Penanda Keberadaan Jamur Ganoderma dari Kebun Kelapa Sawit
}

\section{Analysis of $\mathrm{Cu}$ and $\mathrm{Zn}$ nutrient on weed vegetation as a marker of the presence of ganoderma fungi from oil palm estate.}

\author{
Wismaroh Sanniwati Saragih ${ }^{1,3^{*}}$, Edison Purba $^{2} \&$ Koko Tampubolon ${ }^{1}$ \\ ${ }^{1}$ Program Doktor Ilmu Pertanian, Fakultas Pertanian, Universitas Sumatera Utara, Medan 20155, Indonesia \\ ${ }^{2}$ Program Studi Agroteknologi, Fakultas Pertanian, Universitas Sumatera Utara, Medan 20155, Indonesia. \\ ${ }^{3}$ Program Studi Agroteknologi, Fakultas Pertanian, Universitas Pembinaan Masyarakat Indonesia, \\ Medan 20214, Indonesia. \\ Email: sanniwati@gmail.com
}

\section{ABSTRACT}

Basal stem rot(BSR) in oil palm plants caused by ganoderma fungi has caused the loss of crop production. The presence of the fungi thought to be associated with weed vegetation in the estate which is spread through spores and micelles. Early detection of ganoderma fungi is needed through weed vegetation approach by analysis of $\mathrm{Cu}$ and $\mathrm{Zn}$ nutrient. This research was aimed to determine the relationship of ganoderma fungi presence on $\mathrm{Cu}$ and Zn nutrient in dominant weed from oil palm plantations. This research was conducted at the blocks 17, 16, and 6 of Afdeling VII of Rambutan Estate, Serdang Bedagai Regency and the leaves analysis at Analytical Laboratory of PT. Socfin Indonesia, Medan from July until August 2018. This research method was used with descriptive analytics. This research was taken by 3 types of dominant weed (Cyperus rotundus, Cyclosorus aridus, and Stenochlaena palustris). The results showed that $\mathrm{Zn}$ and $\mathrm{Cu}$ on leaves of the three dominant weed in the oil palm estate were infected with ganoderma fungi lower compared to uninfected, except to Stenochlaena palustris with higher $\mathrm{Cu}$ level. The difference in the percentage of $\mathrm{Zn}$ in the leaves of Cyperus rotundus, Cyclosorus aridus, and Stenochlaena palustris in the oil palm were infected compared to uninfected with ganoderma fungi of $-42.72 \% ;-43.92 \% ;-1.70 \%$ and $\mathrm{Cu}$ nutrient of $-27.13 \%$; $-25.80 \% ;+34.34 \%$. The application of balanced fertilization and proper weed control management can be the initial anticipation in preventing the presence of ganoderma fungi.

Keywords: ganoderma fungi, oil palm, weed, $\mathrm{Cu}$ and $\mathrm{Zn}$ nutrient.

\begin{abstract}
ABSTRAK
Penyakit busuk pangkal batang pada tanaman kelapa sawit yang disebabkan jamur ganoderma telah menyebabkan kerugian produksi tanaman. Kehadiran jamur ini diduga berasosiasi dengan vegetasi gulma yang berada di kebun, yang disebar melalui spora dan miselianya. Deteksi awal keberadaan jamur ganoderma diperlukan melalui pendekataan vegetasi gulma dengan analisis hara $\mathrm{Cu}$ dan $\mathrm{Zn}$. Penelitian ini bertujuan mengetahui hubungan keberadaan jamur ganoderma terhadap kadar hara $\mathrm{Cu}$ dan $\mathrm{Zn}$ pada gulma dominan di perkebunan kelapa sawit.
\end{abstract}


Penelitian ini dilaksanakan di blok 17, 16, dan 6 Afdeling VII Kebun Rambutan Kabupaten Serdang Bedagai dan analisis daun di Laboratorium Analitik PT. Socfin Indonesia, Medan pada bulan Juli -Agustus 2018. Metode penelitian ini menggunakan deskriptif analitik. Penelitian ini mengambil 3 spesies gulma dominan (Cyperus rotundus, Cyclosorus aridus, dan Stenochlaena palustris). Hasil penelitian menunjukkan kadar $\mathrm{Zn}$ dan $\mathrm{Cu}$ pada daun dari ketiga jenis gulma dominan di kebun kelapa sawit terinfeksi jamur ganoderma lebih rendah dibandingkan tidak terinfeksi, kecuali gulma Stenochlaena palustris kadar Cu lebih tinggi. Selisih persentase kadar Zn pada daun ketiga gulma dominan di kebun kelapa sawit terinfeksi dibandingkan tidak terinfeksi jamur ganoderma masing-masing sebesar $-42,72 \%$; $-43,92 \%$ dan $-1,70 \%$ dan hara $\mathrm{Cu}$ masing-masing sebesar $27,13 \% ;-25,80 \%$ dan $+34,34 \%$. Penerapan pemupukan berimbang dan management pengendalian gulma yang tepat dapat menjadi antisipasi awal dalam mencegah kehadiran jamur ganoderma.

Kata kunci: gulma, jamur ganoderma, hara $\mathrm{Cu}$ dan $\mathrm{Zn}$, kelapa sawit.

\section{PENDAHULUAN}

Kelapa sawit (Elaeis quinensis Jacq.) adalah tumbuhan tropis yang berasal dari Afrika Barat. Tumbuhan ini dapat tumbuh di luar daerah asalnya, termasuk Indonesia. Kelapa sawit termasuk tumbuhan pohon yang tingginya dapat mencapai 24 meter. Bunga dan buahnya berupa tandan, serta bercabang banyak. Buahnya kecil, apabila masak berwarna merah kehitaman dan daging buahnya padat. Tanaman kelapa sawit memiliki arti penting bagi pembangunan nasional, Selain mampu menyediakan lapangan kerja, hasil dari tanaman ini juga merupakan sumber devisa Negara yaitu sebagai penghasil minyak, bahan industri maupun bahan bakar (Syahputra et al. 2011).

Gulma yang tumbuh di areal perkebunan kelapa sawit merupakan tumbuhan pengganggu yang dapat merugikan pertumbuhan dan produksi kelapa sawit. Kehadirannya mampu menjadi kompetitor utama dalam memperebutkan unsur hara, air, ruang tumbuh dan cahaya matahari. Gulma yang ada di perkebunan kelapa sawit juga dapat menjadi inang bagi hama dan penyakit untuk tumbuh dan berkembang (Adriadi et al. 2012). Salah satu penyakit berbahaya pada tanaman kelapa sawit adalah penyakit busuk pangkal batang (BPB) yang disebabkan jamur ganoderma.

Ganoderma termasuk soil borne fungi, bersifat parasitik dan patogen tumbuhan yang menyebabkan busuk akar dan batang. Busuk pangkal batang menyebabkan kerugian ekonomi yang serius bagi industri kelapa sawit. Oleh karena itu, busuk pangkal batang dianggap sebagai ancaman serius industri kelapa sawit di negara-negara Asia Tenggara. Sampai saat ini, masih diperlukan tindakan mendeteksi dan mengendalikan secara berkelanjutan (Naher et al. 2013). Mercière et al. (2017) menyatakan bahwa penyebaran serangan jamur ganoderma sangat cepat melalui: (1) kontak akar antar pohon kelapa sawit, (2) spora ganoderma menyebar melalui angin, terbawa serangga, dan (3) spora ganoderma juga dapat tersebar akibat kegiatan panen dan pemeliharaan kebun. Di Indonesia, jamur Ganoderma boninense teridentifikasi sebagai spesies yang paling umum menyerang dan menyebabkan kematian tanaman sampai lebih dari $80 \%$ dari seluruh populasi kelapa 
sawit, serta menyebabkan penurunan produk kelapa sawit per hektar.

Beberapa deteksi dini akan keberadaan jamur ganoderma ini sudah dilakukan melalui penelitian dari berbagai bidang keilmuan. Penelitian keterkaitan populasi gulma dominan dengan keberadaan jamur ganoderma telah dilaporkan Saragih et al. (2018), spesies gulma yang dominan terdapat pada kelapa sawit yang terinfeksi tetapi tidak terdapat pada kelapa sawit yang tidak terserang jamur ganoderma di afdeling VII Kebun Rambutan Serdang Bedagai, yaitu Cyclosorus aridus $(\mathrm{SDR}=14,78 \%)$, Cyperus rotundus $(\mathrm{SDR}=$ 10,60\%), dan Stenochlaena palustris $(\mathrm{SDR}=$ $7,76 \%$ ). Penelitian mengenai hubungan unsur hara mikro terhadap keberadaan jamur ganoderma juga telah dilaporkan Rakib et al. (2017), daun kelapa sawit yang memiliki hara $\mathrm{Cu}$ dan $\mathrm{Zn}$ yang tinggi signifikan lebih rendah terinfeksi jamur ganoderma dibandingkan dengan kelapa sawit tidak terinfeksi di tanah gambut, Serawak, Malaysia. Sarwar, (2011); Gogi et al. (2012), unsur hara mikro $\mathrm{Zn}$ dan $\mathrm{Cu}$ berperan dalam metabolisme asam nukleat, pembelahan sel dan sintesis protein sehingga dapat meningkatkan resistensi tanaman terhadap serangan organisme pengganggu tanaman. Namun belum pernah dilakukan pengkajian khusus tentang hara $\mathrm{Cu}$ dan $\mathrm{Zn}$ pada gulma dominan yang berada di kebun kelapa sawit dalam membuktikan kehadiran gulma sebagai penanda jamur ganoderma. Tujuan penelitian ini untuk mengetahui hubungan keberadaan jamur ganoderma terhadap kadar hara $\mathrm{Cu}$ dan $\mathrm{Zn}$ pada vegetasi gulma yang dominan di kebun kelapa sawit.

\section{BAHAN DAN METODE}

Percobaan ini dilaksanakan pada bulan Juli-Agustus 2018 di Blok 17, Blok 16, dan Blok 6 Afdeling VII, Kebun Rambutan PTPN III, Kabupaten Serdang Bedagai Provinsi Sumatera Utara. Penelitian ini melanjutkan kajian gulma dominan sebagai penanda jamur ganoderma dari Saragih et al. (2018) dengan metode estimasi visual maupun kuadrat (1 m x $1 \mathrm{~m}$ ). Pengkajian sebelumnya diperoleh 3 spesies gulma dominan yaitu Cyclosorus aridus, Cyperus rotundus, dan Stenochlaena palustris. Penelitian ini menggunakan metode deskriptif analisis. Daun ketiga spesies gulma diambil dari masing-masing blok dengan tiga ulangan kemudian dikompositkan. Analisis $\mathrm{Cu}$ dan Zn pada daun dilakukan menggunakan alat spektrofotometer serapan atom (SSA) di Laboratorium Analitik PT. Socfin Indonesia, Medan. Data dianalisis kemudian dideskripsikan.

\section{HASIL DAN PEMBAHASAN}

Hasil analisis $\mathrm{Cu}$ dan $\mathrm{Zn}$ pada daun dari gulma Cyperus rotundus, Cyclosorus aridus, dan Stenochlaena palustris di kebun kelapa sawit yang terinfeksi dan tidak terinfeksi jamur ganoderma (Gambar 1).

Analisis hara $\mathrm{Zn}$ pada daun ketiga gulma dominan disekitar kelapa sawit yang terinfeksi jamur ganoderma lebih rendah dibandingkan tidak terinfeksi. Sedangkan hara $\mathrm{Cu}$ pada gulma Cyperus rotundus dan Cyclosorus aridus yang terinfeksi jamur ganoderma lebih rendah dibandingkan tidak terinfeksi jamur ganoderma dan berbanding terbalik pada gulma 


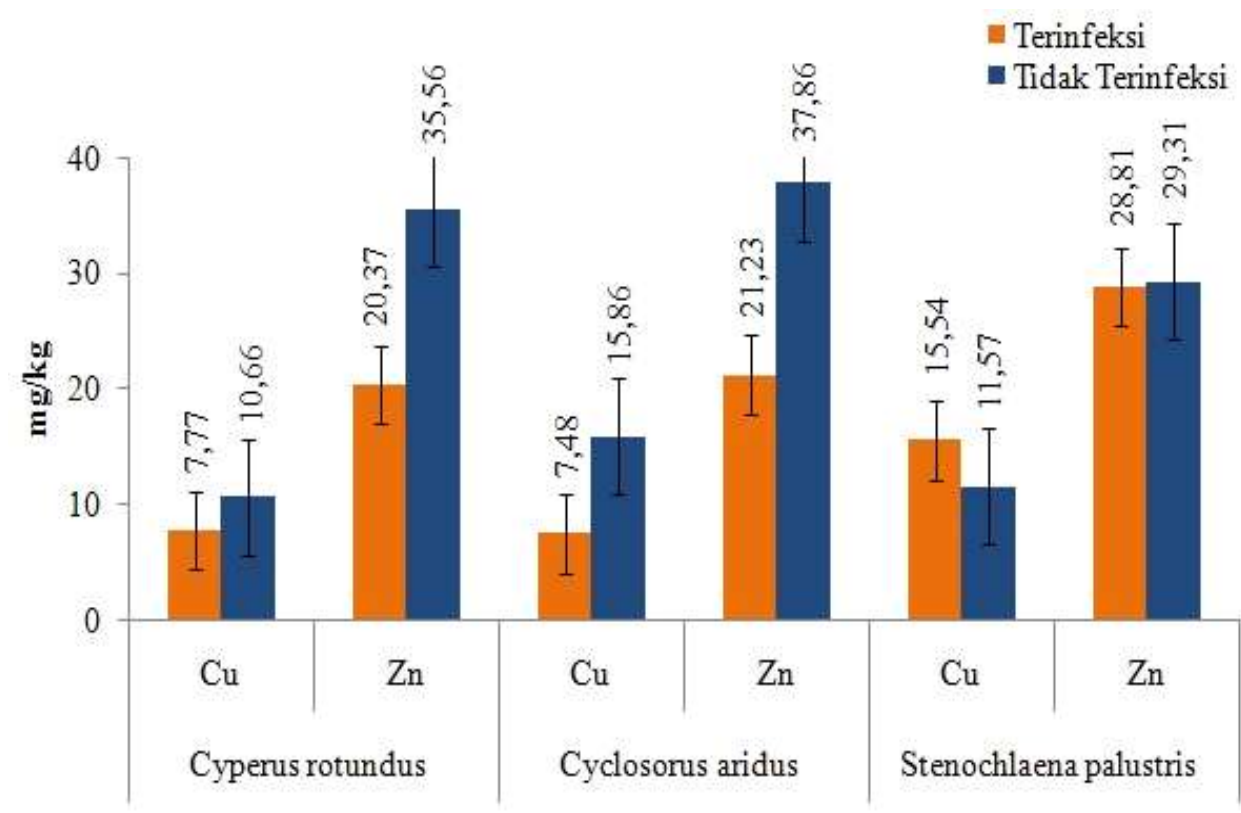

Gambar 1. Analisis Cu dan Zn pada daun gulma Cyperus rotundus, Cyclosorus aridus, Stenochlaena palustris disekitar tanaman kelapa sawit yang terinfeksi dan tidak terinfeksi jamur ganoderma. Garis vertikal menunjukkan \pm standar error.

Stenochlaena palustris. Hal ini dapat membuktikan bahwa defisiensi kadar hara $\mathrm{Cu}$ dan $\mathrm{Zn}$ pada daun gulma diareal piringan maupun gawangan mati pada perkebunan kelapa sawit dapat digunakan sebagai tanaman inang bagi ganoderma untuk perkembangan spora. Serapan hara $\mathrm{Cu}$ dan $\mathrm{Zn}$ pada daun gulma dapat dipengaruhi ketersediaan hara $\mathrm{Cu}$ dan $\mathrm{Zn}$ didalam tanah, kapasitas tukar kation (KTK), C-organik dan ion yang bersifat monovalen seperti ion kalium. Hal ini sesuai dengan pendapat Rakib et al. (2017) menyatakan bahwa kandungan $\mathrm{Cu}$ dan $\mathrm{Zn}$ yang tinggi pada daun kelapa sawit secara signifikan lebih rendah terinfeksi jamur ganoderma dibandingkan dengan kelapa sawit tidak terinfeksi di tanah gambut, Serawak, Malaysia. Menurut Nasution et al. (2016), sebesar $16,8 \%$ intensitas serangan penyakit busuk pangkal batang (Ganoderma sp.) dipengaruhi oleh kandungan
K dalam tanah. Sabrina et al. (2012) melaporkan pemberian campuran $2 \mathrm{mg} / \mathrm{L} \mathrm{Cu}$ dan $4000 \mathrm{mg} / \mathrm{L} \mathrm{Ca}$ dapat menekan 100\% Ganoderma boninense dari 3 bulan setelah inokulasi.

Selisih persentase $\mathrm{Cu}$ dan $\mathrm{Zn}$ pada daun Cyperus rotundus, Cyclosorus aridus, dan Stenochlaena palustris disekitar tanaman kelapa sawit yang terinfeksi dibandingkan tidak terinfeksi jamur ganoderma (Gambar 2).

Daun gulma Cyperus rotundus yang terinfeksi jamur ganoderma memiliki selisih persentase $\mathrm{Cu}$ dan Zn masing-masing sebesar $-27,13 \%$ dan $-42,72 \%$. Demikian juga pada daun gulma Cyclosorus aridus masing-masing sebesar $-52,80 \%$ dan $-43,92 \%$. Namun berbeda dengan gulma Stenochlaena palustris, selisih persentase hara $\mathrm{Cu}(+34,34 \%)$ berbanding terbalik dengan kadar hara Zn (-1,70\%). Hal ini menunjukkan 


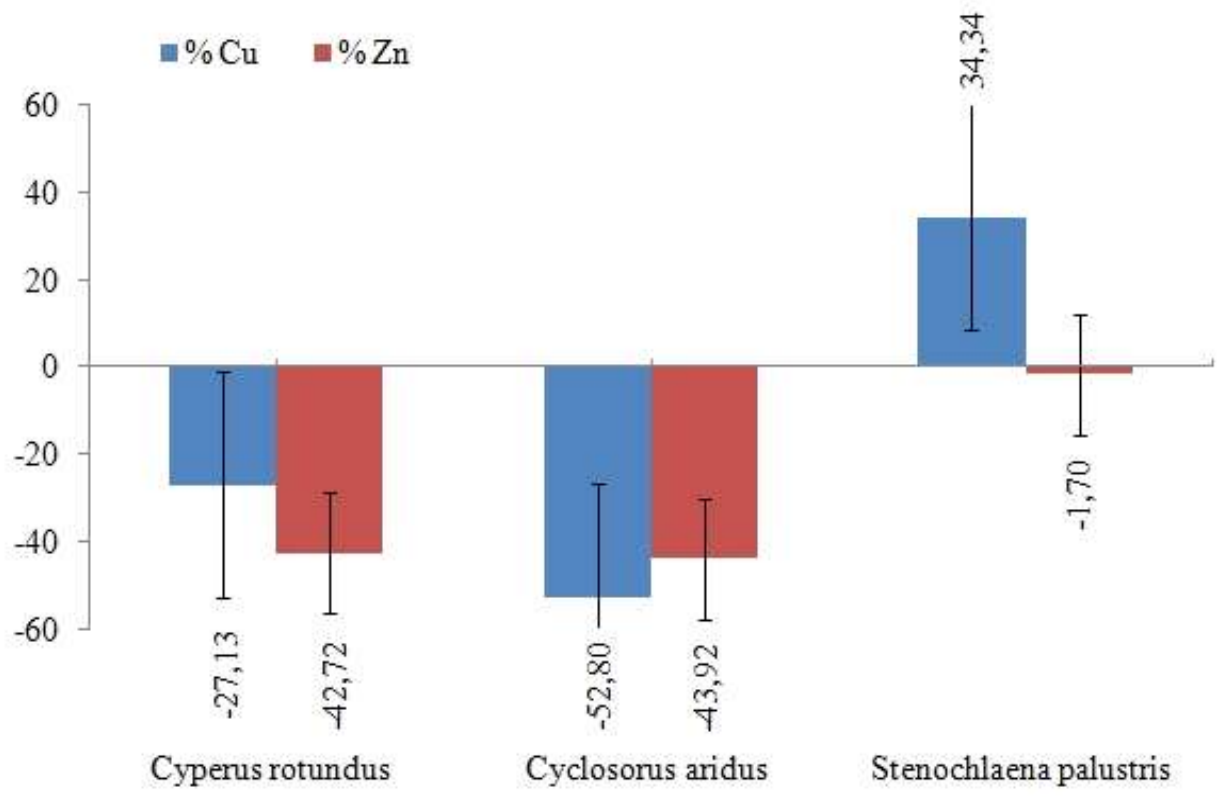

Gambar 2. Selisih persentase kadar Cu dan Zn pada daun Cyperus rotundus, Cyclosorus aridus, Stenochlaena palustris disekitar tanaman kelapa sawit yang terinfeksi dibandingkan tidak terinfeksi jamur ganoderma. Garis vertikal menunjukkan \pm standar error.

bahwa rendahnya hara Zn pada gulma Cyperus rotundus, Cyclosorus aridus, dan Stenochlaena palustris diduga salah satu faktor penyebab spora ganoderma tumbuh dan berasosiasi dengan akar dan daun pada kelapa sawit tersebut. Selain itu, faktor lainnya yang dapat mempengaruhi jamur ganoderma menginfeksi tanaman dapat disebabkan oleh eksudat akar dari gulma maupun kelapa sawit itu sendiri. Hal ini sesuai dengan pendapat Rice, (2007) menyatakan bahwa hara Zn mengakibatkan resistensi tanaman terhadap berbagai penyakit. Mekanisme yang melibatkan Zn dalam resistensi penyakit tidak jelas tetapi Zn bertindak sebagai ko-faktor untuk berbagai enzim. Duffy, (2007) kekurangan hara Zn pada tanaman karet (Hevea brasiliensis) menyebabkan predisposisi terhadap infeksi Oidium heveae. Nelson et al. (2011), kadar $\mathrm{Zn}$ yang rendah di tanah dan jaringan daun berasosiasi dengan penyakit busuk Phytophthora pada kakao di Papua Nugini. Evans et al. (2007) kekurangan hara tembaga $(\mathrm{Cu})$ dapat mengurangi lignifikasi dalam xilem. Tembaga memiliki efek toksik langsung pada patogen. Ketersediaan hara Cu dapat melindungi anggur dari penyakit bulai yang disebabkan oleh Plasmopara viticola dan Pseudoperonospora humuli. Saidi et al. (2007) juga menyatakan bahwa beberapa senyawa metabolit (eksudat akar) seperti karbohidrat, asam amino dan asam-asam organik lainnya yang dikeluarkan oleh tanaman inang dapat digunakan jamur mikoriza vesikular arbuskular untuk proses pertumbuhan dan perkembangannya serta penyebarannya.

Serapan hara $\mathrm{Cu}$ dan $\mathrm{Zn}$ pada daun gulma di perkebunan kelapa sawit dapat sebagai antisipasi dini dalam mencegah penyebaran spora jamur ganoderma. Berdasarkan temuan diatas, diperlukan management 
pengendalian gulma yang tepat dan penerapan pemupukan yang berimbang bagi perkebunan kelapa sawit dalam mengendalikan kehadiran jamur ganoderma.

\section{KESIMPULAN}

Analisis kadar Zn pada daun gulma Cyperus rotundus, Cyclosorus aridus, dan Stenochlaena palustris di kebun kelapa sawit terinfeksi jamur ganoderma lebih rendah dibandingkan tidak terinfeksi. Hara $\mathrm{Cu}$ pada daun gulma Cyperus rotundus dan Cyclosorus aridus di kebun kelapa sawit terinfeksi jamur ganoderma lebih rendah dibandingkan tidak terinfeksi dan berbandik terbalik pada gulma Stenochlaena palustris. Selisih persentase kadar Zn pada daun Cyperus rotundus, Cyclosorus aridus, dan Stenochlaena palustris di kebun kelapa sawit terinfeksi dibandingkan tidak terinfeksi jamur ganoderma masing-masing sebesar $-42,72 \%$; 43,92\%; dan -1,70\% sedangkan kadar Cu masingmasing sebesar $-27,13 \%$; $-52,80 \%$; dan $+34,34 \%$. Defisiensi hara $\mathrm{Zn}$ dan $\mathrm{Cu}$ pada gulma berpengaruh terhadap kehadiran dan perkembangan spora jamur ganoderma.

\section{UCAPAN TERIMA KASIH}

Penulis mengucapkan terima kasih kepada Lembaga Pengelola Dana Pendidikan (LPDP) yang telah memberikan Beasiswa Unggulan Dosen Indonesia Dalam Negeri (BUDI DN).

\section{DAFTAR PUSTAKA}

Adriadi, A., Chairul., and Solfiyeni. 2012. Analisis Vegetasi Gulma pada Perkebunan Kelapa Sawit (Elaeis quineensis Jacq.) di Kilangan, Muaro Bulian, Batang Hari. Jurnal Biologi Universitas Andalas. 1(2): 108-115. https:// doi.org/10.25077/jbioua.1.2.\%25p.2012

Duffy, B. 2007. Zinc and Plant Disease. In Mineral Nutrition and Plant Disease, edited by Datnoff, L.E., Elmer, W.H, and Huber, D.M. St. Paul, Minn: American Phytopathological Society. 155-178 p.

Evans, I., E. Solberg., dan D.M. Huber. 2007. Copper and Plant Disease. In Mineral Nutrition and Plant Disease, edited by Datnoff, L.E., Elmer, W.H, and Huber, D.M. St. Paul, Minn: American Phytopathological Society. 177-188 p.

Mercière, M., R. Boulord., C. Carasco-Lacombe., C. Klopp., Y.P. Lee., J.S. Tan., S.S.R. SyedAlwee., A. Zaremski., H. DeFranqueville., F. Breton., and L. CamusKulandaivelu. 2017. About Ganoderma boninense in Oil Palm Plantations of Sumatra and Peninsular Malaysia: Ancient Population Expansion, Extensive Gene Flow and Large Scale Dispersion Ability. Fungal Biology. 121(6-7): 529-540. doi: 10.1016/ j.funbio.2017.01.001.

Naher, L., U.K. Yusuf., A. Ismail., S.G. Tan., and M.M.A. Mondal. 2013. Ecological Status of Ganoderma and Basal Stem Rot Disease of Oil Palms (Elaeis guineensis Jacq.). Australian Journal of Crop Science. 7(11): 1723-1727.

Nasution, T.D.S., Supriadi., dan M.M.B. Damanik. 2016. Survey dan Pemetaan Status Hara K dan C-Organik pada Lahan Kelapa Sawit yang Terserang Ganoderma di PT. PD PATI Kabupaten Aceh Tamiang. Jurnal Online Agroekoteknologi. 4(4): 2238-2244. 
Nelson, P., M. Webb., S. Berthelsen., G. Curry., D. Yinil., and C. Fidelis. 2011. Nutritional Status of Cocoa in Papua New Guinea. Edited by Australian Centre for Internasional Agricultural Research. vol. 76, Aciar Technical Reports Canberra: Australian Centre for International Agricultural Research.

Rakib, M.R.M., C.F.J. Bong., A. Khairulmazmi., A.S. Idris., M.B. Jalloh., and O.H. Ahmed. 2017. Association of Copper and Zinc Levels in Oil Palm (Elaeis guineensis) to the Spatial Distribution of Ganoderma Species in the Plantations on Peat. Journal of Phytopathology. 165(4): 276-282. doi: 10.1111/jph.12559.

Rice, R.W. 2007. The Physiological Role of Minerals in Plants. In Mineral Nutrition and Plant Disease, edited by Datnoff, L.E., Elmer, W.H, and Huber, D.M. St. Paul, Minn: American Phytopathological Society. Hlm. 9-30.

Sabrina, N.A.A., M. Sariah., and A.R. Zaharah. 2012. Suppression of Basal Stem Rot Disease Progress in Oil Palm (Elaeis guineensis) after Copper and Calcium Supplementation. Pertanika Journal of Tropical Agricultural Science. 35(S): 13-24.

Saragih, W.S., E. Purba., and K. Tampubolon. 2018. Identification and Analysis of Weed Vegetation as Ganoderma Presence Marker on Oil Palm Plantation. Jurnal Natural. 18 (3): 135-140. doi: 10.24815/jn.v0i0.11595.

Saidi, A.B., S.W. Budi., and C. Kusmana. 2007. Status Cendawan Mikoriza Arbuskular Hutan Pantai dan Hutan Mangrove Pasca Tsunami (Studi Kasus di Provinsi Nangroe Aceh Darussalam dan Pulau Nias). Forum Pascasarjana. 30(1): 13-25.

Syahputra, E., Sarbino., and S. Dian. 2011. Weeds Assessment di Perkebunan Kelapa Sawit Lahan Gambut. Jurnal Perkebunan dan Lahan Tropika. 1(1):37-42. http://dx.doi.org/ 10.26418/plt.v1il.120. 